The Labore Journal of Economics

$11: 1$ (Summer 2006) pp. 19-34

\title{
Trade Liberalization and Economic Development: Evidence from Pakistan
}

\author{
Bushra Yasmin, Zainab Jehan, Muhammad Ali Chaudhary*
}

\begin{abstract}
Unrestricted trade stimulates economic growth and bridges socioeconomic gaps existing in different countries of the world. Pakistan has adopted trade liberalization policies since the late 1980s with the same expectations. This study has empirically analyzed how trade liberalization has affected economic development in the country. Its effects have been examined with respect to four measures of economic development: per capita GDP, income inequality, poverty and employment over the period from 1960-2003. The main analysis is based on a simultaneous equation model. Keeping in view the simultaneity of the chosen development measures, the model is estimated with the 2SLS technique of regression analysis. The analysis shows that, over the study period, trade liberalization has not affected all the chosen indicators of development uniformly. It has affected employment positively but per capita GDP and income distribution negatively. However, it has not affected poverty in any way. The obvious message is that trade liberalization has not affected all the indicators of development favorably in Pakistan. It thus implies the need of a cautious move towards liberalization. The focus of trade liberalization should be to bring about improvement in the performance of mediating factors and to focus exports on labor-intensive products.
\end{abstract}

\section{JEL Classification: F41}

Keywords: Trade Liberalization, Economic Development, Poverty

\section{Introduction}

The world is rapidly transforming into a global village. Trade has contributed to this transformation more significantly than any other factor. In fact, the high economic, social, cultural, political, human and intellectual

\footnotetext{
* The authors are Lecturers in Economics and Professor of Economics, Fatima Jinnah Women University, Rawalpindi, respectively.
} 
integration witnessed in the world in the recent past is due primarily, though not exclusively, to trade among its different countries. Further, trade has contributed much more to the development of the world economies than any other factor. It is because different nations interact with each other through trade that it tends to bring about the desired change through the exchange of goods, services, skills, knowledge and expertise. In the process, trade increases the availability of choices, improves the level and distribution of income, increases opportunities for enhancement of technical capacities and finally motivates people to accelerate the process of change in their countries. This desired process of change signifies development. Development, in turn, is manifested in the enhanced work capacity of the people, augmented empowerment of individuals and thereby, high rates of participation in productive activities. Thus, trade and development go hand in hand and therefore the strategies adopted in the case of the former have a strong bearing on the latter.

A number of market-oriented moves have surged during the last couple of decades in the world. In the wake of these moves, the global trend has also witnessed the liberalization of the capital account, foreign exchange, credit, domestic consumption and trade in different countries. However, the area which has received unprecedented emphasis in various economies is trade liberalization. Trade liberalization denote the reduction in barriers to the movement of goods and services in international trade. In the words of Bhagwati and Krueger, "any policy which reduces the antiexport bias will lead towards liberalization of trade" and reduction in the import license premium is the fundamental step towards a liberalized trade regime. ${ }^{1}$ A new explanation by Edwards (1993) describes a liberal trade regime as one in which all trade distortions including import tariffs and export subsidies are completely eliminated.

The new growth theory argues that trade liberalization expands the market, induces an increase in research and development, reallocates employment to more innovative activities that require more human capital and increases knowledge flow among countries. Other than benefits, some costs are also associated with trade liberalization. A substantial problem arising from reducing trade barriers in the wake of trade liberalization is the loss in tariff revenue that accounts for 10-20 percent of government revenue in developing countries. If tariffs are reduced or eliminated, these countries will have to impose large increases in other taxes in order to keep their budgets in line, causing some economic distortions. The move to trade liberalization is also likely to lead to large disruptions in agriculture. If

${ }^{1}$ c. f., Edwards (1993) 
barriers to agricultural imports are removed too quickly, it can lead to largescale displacement of the rural population. Standard economic models implicitly assume that these people are re-employed in other sectors of the economy, but rapid liberalization can lead to substantial unemployment and underemployment, as well as dangerous levels of social and economic instability. This may also lead to an uneven distribution of gains and pains, where the gains are distributed across the economy, while the burdens of adjustments are borne mainly by a particular group as put forward by the Human Development Report (2003).

In fact, trade liberalization has become the key element of any development policy since the late 1970s when economic policy at the global level underwent certain fundamental changes. The formation of the World Trade Origination (WTO) in 1995 provided an impetus to the process of trade liberalization. It provides a platform for negotiating trade related disputes among different countries of the world. The basic purpose of this organization is to facilitate the process of liberalizing trade and other trade related aspects at the international level.

As expected, different countries use different approaches for acquiring gains from trade liberalization. For example, East Asian countries moved towards an outward development strategy of import substitution and government control by the mid 1960s. ${ }^{2}$ This change in development strategies enabled these countries not only to improve their gross domestic product growth rate, exports and living standards but also enabled them to sustain their development during the years of the oil shock in the 1970s as well as in the debt and recession years of the early 1980s. Consequently, their per capita income was four to five times higher in the 1990s than in the 1960s. More specifically, the per capita incomes of Hong Kong, Korea, Singapore and Taiwan rose at an annual rate of 6.2 percent, 7.1 percent, 6.5 percent, and 8.1 percent respectively, in the period 1965-1990 (Behrman and Srinivasan, 1995).

A vast body of literature provides ample evidence of significant contributions, either positive or negative, of trade liberalization to the development of the world. For instance, Greenaway et. al. (2002) conducted a study to analyze the relationship between trade liberalization and the growth rate of GDP for 73 developing countries. This cross-country analysis was based on three different measurements of liberalization: First through non-tariff

${ }^{2}$ From the mid 1950s, Taiwan provides various incentives to its export sector for the encouragement of exports. Hong Kong was a virtual laissez-faire economy. Korea applied an export-oriented regime in the early sixties, and Singapore started her impressive growth breaking away from Malaya in the mid sixties 
barriers, average tariff, black market exchange rate premium, whether the economy is socialist or not, and whether state monopoly exists over major exports; Secondly, through level of quotas, tariff, and export impediments and promoters and exchange rate misalignment; Lastly, with a dummy variable for the structural adjustment program, a World Bank (WB) indicator.

Empirical results of this study were obtained by using the ordinary least squares (OLS) technique with three different time periods for three different indicators. Results obtained for the short run from the first two indicators showed the positive and significant impact of trade liberalization on growth while the WB indicator showed an insignificant impact of trade liberalization on growth. Moreover results from all indicators showed that liberalization affects the growth rate of GDP with a lag in the long run.

Similarly, Kemal et. al., (2002) empirically tested the macro economic determinants of growth in Pakistan by taking into account the variables supposed to have the most significant impact on the growth rate such as investment in physical capital, population growth, government consumption, inflation and trade liberalization. The OLS technique of estimation was used for the time period 1959-60 to 2000-01. Empirical results showed that openness appeared to have an insignificant impact on economic growth due to inconsistent and unavailable data on many other important variables, and a variety of political, institutional and infrastructure problems faced by Pakistan. A common argument of both these studies discussed above is that trade liberalization affects different aspects of economic development differently due to different government policies and institutional factors. The specifications of models and techniques of their estimation also show different effects of trade liberalization. This conclusion is also supported by some other studies as well.

The study of Irwin et. al., (2002) investigating the relationship between trade liberalization and income growth for countries engaged in bilateral trade for different time periods, demonstrated that more open economies enjoy a higher level of per capita income. This study used the instrumental variable (IV) technique of estimation. Mohsin et. al. (2001) aimed to explain the impact of openness on the poverty level in Pakistan for the time period 1963-64 to 1993-94. The study demonstrates that poverty has declined with trade liberalization in Pakistan using the head count index method for measuring poverty and the sum of imports and exports as a percentage of GDP for openness. Similarly, Yang and Huang (1997) suggest that a decline in the economy wide tariff leads towards more equitable distribution of income in China using a Computable General Equilibrium (CGE) mode1. 
Moreover, Waczairg (2001) carried out an empirical investigation for the indirect linkages between trade liberalization and growth by first checking the impact of the former on six different channels of growth and then the effect of these channels on the latter for 57 countries during the time period 1970-1989. ${ }^{3}$ Using the simultaneous equations technique the parameters were jointly estimated through three stage least squares. Results of the study demonstrated that trade openness has a positive impact on growth through five determinants, namely the black market premium, manufactured exports, investment rate, foreign direct investment, macro policy quality, while it has a negative but insignificant impact on growth through government size (measured by government consumption). Investment appears to be the most significant channel through which trade liberalization affects growth.

Most of the studies reviewed so far have analyzed the impact on different indicators of development separately. Mainly economic growth is considered as the main indicator of development ignoring all other aspects or dimensions of development. The positive relationship between trade liberalization and economic growth is a necessary but not a sufficient condition for development, and several other factors must be taken into consideration to find out the impact of trade liberalization on economic development.

This study has tried to take into account the most crucial elements of development such as per capita GDP, income inequality measured by the Gini coefficient, the poverty level, and employment over the period from 1960-2003 for Pakistan. This study provides recent evidence for the impact of trade liberalization on the economy of Pakistan using a simultaneous equations model keeping in view the simultaneity of various factors.

The rest of the study is organized as follows: Trade polices announced so far in Pakistan with reference to liberalization are discussed in detail in the second part of the study. The third part presents the model specification and estimation procedure. In the fourth part, data and construction of different variables are discussed. Empirical results are explained in the fifth part. The final section concludes the study and lists certain policy implications.

\section{Historical Review of Trade Liberalization in Pakistan}

The early years of Pakistan's economy can be characterized by a weak industrial base, dominance of the agriculture sector, lack of wellorganized infrastructure, and above all eco-political instability. The main objective of the policies of those years was to strengthen the industrial base.

\footnotetext{
${ }^{3}$ Black market premium, manufactured exports, investment rate, foreign direct investment, macro policy quality, and government size.
} 
To this end, Pakistan adopted a restricted trade regime and protected its domestic industries with high tariff and non-tariff barriers.

The period of the sixties was the period in which the industrial base was laid and in which rapid expansion of large scale manufacturing industries started in the country. While the highly protected trade regime remained effective in this period, some additional policies were introduced to encourage industrial exports from the country: an overvalued exchange rate, export bonuses, preferential credit access to industries with export potential and automatic renewal of import licenses. Consequently, both industrial production and exports registered a reasonable increase during the 1960s. However, industrial expansion did not continue at the same rate in the next decade. In fact, it suffered a setback in the next decade due to the nationalization of industries. Although the government nationalized different types of industries in the country, it took three additional trade liberalization measures to encourage exports during this period: devaluation of the Pakistani Rupee by $57 \%$ in 1972, elimination of the export bonus scheme, and the discontinuation of restrictive licensing scheme. These steps stimulated exports especially of manufactured products.

Although trade policies were modified continuously in Pakistan, changes of particular significance were made after the formulation of the new trade policy in 1987. After the incorporation of the other changes, the trade policy led, inter alia, to a reduction in tariff slabs from 17 to 10 and introduction of a uniform tax in place of commodity based sales taxes. In fact, the government focused in this decade mainly on enhancing the role of private sector in the economy, increasing the competitiveness and efficiency of the domestic industrial sector, and promoting exports. The specific measures that the government took in pursuance of these objectives related to the provision of different fiscal incentives such as tax holidays, tariff cuts and other profit augmenting opportunities to the exporters. More specifically, the maximum tariff was reduced from 225 percent in 1986-87 to 70 percent in 1994-95. Similarly, the number of custom duty slabs were reduced from 13 to 5. Further, the flexible exchange rate system introduced earlier was kept in effect during this decade.

The years 2000-2003 have witnessed the introduction of such policies as promotion of liberalization, deregulation, and reduction in the cost of doing business; these policies have laid equal emphasis on encouraging a stable macro economic framework in terms of inflation, interest rate and exchange rate. Further, they have also concentrated on the promotion of export of services, which had not received proportional attention in the past. In fact, they have made the promotion of services an integral component of 
the overall trade policy of the country, so much so that the government has set export and import targets of US \$ 12.1 and 12.8 billion for the current year. The achievement of these targets will reduce the trade deficit of the country to less than US\$ 1.0 billion (GOP, 2004).

\section{Model Specification and Estimation Procedure}

The effect of trade liberalization on the economic development of Pakistan is to be measured as mentioned before, by its effects on the level of per capita gross domestic product, poverty, inequality of income distribution and employment. These indicators are taken from the definition of development presented by Dudley Seers in 1972 .

Theoretically, these indicators of development are assumed to affect and to be affected by each other. For example, employment level and per capita GDP are mutually dependent on each other. Similarly, per capita GDP and the Gini coefficient, according to Kuznet's hypothesis, are interdependent. In econometric terms such interdependence among the endogenous variables gives rise to the problem of simultaneity across them. As such, simultaneity among the chosen variables necessitates the formulation of the model and its estimation in a way that the analysis yields valid results. To this end, we have specified a simultaneous equations model, as shown below, and estimated by using the 2SLS regression technique.

$$
\begin{aligned}
& L P_{t}=\alpha_{0}+\alpha_{1} L G_{t}+\alpha_{2} L P G D P_{t}+\alpha_{3} L E M P_{t}+\alpha_{4} L T L_{t}+\varepsilon_{\mathrm{t}} \\
& L G_{t}=\beta_{0}+\beta_{1} L P G D P_{t}+\beta_{2} L C P I_{t}+\beta_{3} L T L_{t}+\varepsilon_{\mathrm{t}} \\
& L P G D P_{t}=\gamma_{0}+\gamma_{1} L E M P_{t}+\gamma_{2} L H K_{t}+\gamma_{3} L I N V_{t}+\gamma_{4} L T L_{t}+\gamma_{5} T G+\varepsilon_{\mathrm{t}} \\
& L E M P_{t}=\lambda_{0}+\lambda_{1} L P G D P_{t}+\lambda_{2} L W_{t}+\lambda_{3} L I N V_{t}+\lambda_{4} T G+\lambda_{5} L T L_{t}+\varepsilon_{\mathrm{t}}
\end{aligned}
$$

Where $P$ denotes poverty, $G$ household Gini coefficient, $P G D P$ per capita gross domestic product, $E M P$ employed labor force, inflation is measured by the $C P I$ index, $H K$ human capital, $W$ real wages, $I N V$ ratio of domestic investment to $G D P, T G$ type of government represented by dummy variable with 1 for political government and 0 otherwise, and $T L$ trade liberalization. Equation 1 depicts the effect of trade liberalization on the poverty level in Pakistan. Similarly, equation 2 shows the impact of trade liberalization on the distribution of income. The next equation determines the impact of trade liberalization on PGDP. Finally, the last equation of the model examines the impact of trade liberalization on the level of employment in Pakistan. 
As is obvious, the model specified for this analysis comprises four mutually dependent equations. The dependent variables of these equations, which are endogenous variables of the model, are poverty, the Gini coefficient, per capita income, and the employment level. The explanatory exogenous variables are inflation, human capital, ratio of investment to $G D P$, type of government, real wages and lagged value of $P G D P$ and trade liberalization index.

How the variables included in the model are formulated is explained below.

\begin{tabular}{|c|c|}
\hline les & Description \\
\hline $\begin{array}{l}\text { Per capita Gross } \\
\text { Domestic } \\
\text { Product }\end{array}$ & $\begin{array}{l}\text { GDP is the value of all the final goods and services } \\
\text { produced in Pakistan during a year. PGDP is determined } \\
\text { by dividing the GDP by population of the country. }\end{array}$ \\
\hline Poverty & $\begin{array}{l}\text { Poverty for the purpose of this study is measured by } \\
\text { Head Count Ratio Index. }\end{array}$ \\
\hline $\begin{array}{l}\text { Employment } \\
\text { Leve1 }\end{array}$ & $\begin{array}{l}\text { Employed labor force is that portion of the total labor } \\
\text { force which is employed in paid jobs and self-employed. }\end{array}$ \\
\hline oefficient & $\begin{array}{l}\text { The Gini coefficient measures income inequality. It is } \\
\text { based on the percentage share of income received by } \\
\text { different proportions of the population. }\end{array}$ \\
\hline $\begin{array}{l}\text { Type of } \\
\text { Government }\end{array}$ & $\begin{array}{l}\text { It is represented by dummy variables with } \mathrm{D}=1 \text { for } \\
\text { Political Government and } 0 \text {, otherwise. }\end{array}$ \\
\hline Human Capital & $\begin{array}{l}\text { Human capital is measured and represented by primary } \\
\text { level enrollment rates (in thousands) for the whole } \\
\text { economy. }\end{array}$ \\
\hline Inflation & $\begin{array}{l}\text { Inflation is defined as the annual rate of increase in } \\
\text { prices and is represented by the Consumer Price Index. }\end{array}$ \\
\hline Real wages & $\begin{array}{l}\text { Real wages are the payment made by the employers to } \\
\text { their employees for the work done. Real wages were } \\
\text { constructed by dividing the annual nominal wages by } \\
\text { the corresponding real CPI. }\end{array}$ \\
\hline $\begin{array}{l}\text { Gross } \\
\text { Investment } \\
\text { GDP ratio }\end{array}$ & $\begin{array}{l}\text { It accounts for both the public and private investment } \\
\text { that has taken place in the economy over the study } \\
\text { period. }\end{array}$ \\
\hline $\begin{array}{l}\text { Trade } \\
\text { Liberalization }\end{array}$ & $\begin{array}{l}\text { Two measures are used to measure trade liberalization. } \\
\text { First, the trade-GDP ratio that is obtained by dividing } \\
\text { the sum of exports and imports by GDP. Second, } \\
\text { import duties as percentage of total imports. }\end{array}$ \\
\hline
\end{tabular}


The analysis is based on the national time series data for the time period from 1959-60 to 2002-03. All the variables used in the study are measured in millions of rupees at constant market prices with 1990-91 as the base year. For some of the years, data was missing for poverty and the Gini coefficient and was filled by interpolation. The data is collected from different sources. The Pakistan Economic Survey (various issues) was used for data collection on poverty, Gini coefficient, GDP, population, Consumer Price Index, human capital, employed labor force, imports, exports and GDP deflator. Data on wages is collected from the Pakistan Labor Force Survey (various issues). The data on import duties is collected from the CBR Yearbook published by the Central Board of Revenue (CBR).

\section{Justification of Variables}

Poverty as one of the measures of economic development of an economy is expected to be reduced in response to a rise in PGDP and EMP. As such, poverty is a priori expected to be negatively related to PGDP and EMP. Trade liberalization is expected to reduce poverty by virtue of it increasing the inflows of goods and services in the economy. Excess supply of goods and services, in turn, is expected to cause a decline in prices and thus increase the standard of living of the people of the country.

Next, distribution of income as a measure of income inequality in the economy is expected to be affected by PGDP, inflation and trade liberalization. Specifically, PGDP can increase or decrease the value of the Gini coefficient in accordance with the Kuznets hypothesis of interdependence, which assumes a U-shaped relationship between PGDP and the Gini coefficient. High inflation is theoretically expected to show a positive relationship with the Gini coefficient. As far as trade liberalization is concerned, its effect on income distribution is difficult to predict. It may have worsened or alleviated the distribution of income in Pakistan.

The level of per capita GDP, which is included as another dependent variable indicates the degree of development of a country. In general, high and rising PGDP indicates that development is taking place in the economy. Trade liberalization, EMP and human capital are expected to affect PGDP positively. The investment level is also included in the model for the same reason that it can increase PGDP through the multiplier effect. The type of government that existed in the country over different periods of time is represented in the model by a dummy variable to capture the effect of political and institutional factors on the development of the economy. A democratic government is expected to have a positive and a military regime a negative effect on development. 
Lastly, labor force employment is expected to be positively affected by PGDP positively. The type of government also has a similarly important bearing on employment. Also, the employment level is expected to be positively affected by trade liberalization for it increases the access to cheap raw material and capital machinery, which promote development opportunities in a country.

\section{Estimation Technique}

The model under consideration is constrained to be over identified. Therefore, it is estimated with the two-stage least square (2SLS) method. The basic idea behind 2SLS is to replace the endogenous explanatory variable by a linear combination of the predetermined variables in the model and use them as explanatory variables instead of the original endogenous variables. The 2SLS method thus resembles the instrumental variable method of estimation in that the linear combination of the predetermined variables serves as an instrument, or a proxy for the endogenous variables. This technique completes the analysis in two stages. In the first stage, it computes the structural equations by regressing endogenous variables on all the predetermined variables in the system in which interdependence among variables is removed, because structural equations are those in which endogenous variables are expressed solely in terms of the predetermined variables and stochastic disturbances. As such, the application of the OLS technique to the reduced form equation gives the structural or reduced form coefficients. These structural form coefficients are substituted in primary equations. The estimation of those equations again by OLS technique completes the second stage of the estimation and yields unbiased and consistent coefficients.

The required regression analysis is performed in terms of two models with one using an openness index and the second the share of import duties in total imports as a reflection of trade liberalization. However, the results for the former measure are quoted, being more precise. For the estimated mode1, $\operatorname{logs}$ of the variables were used. The values of the variables included were expressed in their logarithms.

\section{Empirical Results and Interpretation}

Empirical results of the model, in which the openness index (sum of export and import as a percentage of GDP) is used to represent trade liberalization, are reported in Table $1 .^{4}$

\footnotetext{
${ }^{4}$ Since the results for openness as a trade liberalization measure appeared to be more comprehensive, the results for openness are discussed in detail while the results for import duties as a percentage of total imports as a trade liberalization measure are provided in the appendix for reference.
} 
Table-1: Estimates of Simultaneous Equation Model

\begin{tabular}{|c|c|c|c|c|}
\hline Variables & $\begin{array}{l}\text { Eq. } 1 \\
\text { (L P) }\end{array}$ & $\begin{array}{l}\text { Eq. } 2 \\
\text { (LG) }\end{array}$ & $\begin{array}{c}\text { Eq. } 3 \\
\text { (LPGDP) }\end{array}$ & $\begin{array}{c}\text { Eq.4 } \\
\text { (LEMP) } \\
\end{array}$ \\
\hline $\mathrm{C}$ & $\begin{array}{l}-0.656 \\
(-0.0477)\end{array}$ & $\begin{array}{l}0.550 * * \\
(2.110)\end{array}$ & $\begin{array}{c}0.679 * \\
(3.612)\end{array}$ & $\begin{array}{c}-0.401^{*} \\
(-5.531)\end{array}$ \\
\hline LGINI & $\begin{array}{c}0.0923 \\
(0.318)\end{array}$ & - & - & - \\
\hline LPGDP & $\begin{array}{l}-1.749 * \\
(-2.331)\end{array}$ & $\begin{array}{c}-0.804 * \\
(-4.459)\end{array}$ & - & $\begin{array}{r}0.908 * \\
(19.025)\end{array}$ \\
\hline LEMP & $\begin{array}{l}-3.982^{*} \\
(-5.210)\end{array}$ & - & $\begin{array}{c}1.581^{*} \\
(3.651)\end{array}$ & - \\
\hline LCPI & - & $\begin{array}{c}0.237^{*} \\
(4.342)\end{array}$ & - & - \\
\hline LHK & - & - & $\begin{array}{l}-0.205 \\
(-1.174)\end{array}$ & - \\
\hline LINV & - & - & $\begin{array}{c}0.0425 \\
(0.549)\end{array}$ & $\begin{array}{c}-0.046 \\
(-0.828)\end{array}$ \\
\hline TG & - & - & $\begin{array}{l}0.0584^{*} \\
(2.222)\end{array}$ & $\begin{array}{c}-0.029 * \\
(-2.407)\end{array}$ \\
\hline W & - & - & - & $\begin{array}{c}-0.052 \\
(-1.263)\end{array}$ \\
\hline $\mathrm{TL}$ & $\begin{array}{c}-0.119 \\
(-1.498)\end{array}$ & $\begin{array}{l}0.085^{* *} \\
(2.010)\end{array}$ & $\begin{array}{l}-0.175^{* * *} \\
(-1.797)\end{array}$ & $\begin{array}{c}0.108^{*} \\
(2.596)\end{array}$ \\
\hline $\mathrm{R}^{\ulcorner} 2$ & 0.88 & 0.61 & 0.96 & 0.98 \\
\hline D.W & 1.046 & 1.445 & 1.184 & 1.001 \\
\hline AR (2) & $\begin{array}{c}1.011 \\
(75.50)\end{array}$ & $\begin{array}{c}0.291 \\
(2.23)\end{array}$ & $\begin{array}{c}0.235 \\
(1.23) \\
\end{array}$ & $\begin{array}{c}0.303 \\
(1.47)\end{array}$ \\
\hline
\end{tabular}

Note: 1) t-values are in parentheses.

2) *,** and $* * *$ indicate significance at $1 \%, 5 \%$ and $10 \%$ level of significance, respectively.

In Table-1 the first column provides the list of variables. The second column provides the estimates obtained from $1^{\text {st }}$ equation of the model with dependent variable $\log$ of poverty already specified. The third column 
reports the results of the $2^{\text {nd }}$ equation with $\log$ of income inequality as the dependent, the fourth column reports the $3^{\text {rd }}$ equation's result with $\log$ of GDP per capita as the dependent variable and the last column provides the estimates of the $4^{\text {th }}$ equation with $\log$ of employment as dependent one. Table-1 indicates that the number of theoretically compatible and satisfactory results in terms of signs and size of coefficients exceed that of incompatible results. The adjusted $\mathrm{R}^{2}$ values are also reasonably high. More specifically, the adjusted $\mathrm{R}^{2}$ values are $0.88,0.61,0.96$ and 0.98 respectively for the four equations. The problem of auto-correlation, where detected in the model through the Durbin Watson test, was removed by applying auto regressive scheme two, $\mathrm{AR}(2) .^{5}$

What has been the impact of trade liberalization on different indicators of development is important to know for different academic and practical policy purposes. It is clear from Table 1 that trade liberalization has not been able to reduce poverty in the country. It means that poverty has continued to increase regardless of the effort at trade liberalization. However, PGDP appears to have had a significant negative effect on poverty. Specifically, a one percent increase in PGDP has led to 1.7 percent decrease in the level of poverty in the country, showing more than unitary elastic relationship between poverty and PGDP. Earlier, Mohsin et. al. (2001) obtained similar results regarding the reduction in poverty with increase in PGDP. Employment, which is assumed at least theoretically to be an important factor in the reduction of the poverty level, has been found to be negative and statistically significant at the 1-percent level of significance. In fact, a one percent increase in employment opportunities has reduced poverty in the country by nearly 4 per cent. As such, employment has turned out to be the most important factor in the reduction of poverty and thereby in the promotion of development in the country. In fact, this analysis shows that trade liberalization has not reduced poverty in the country due perhaps to weak institutional framework, political instability and macro economic instability. Actually, trade liberalization the policy is not adopted with the motive of poverty elimination.

In the case of the second development indicator, distribution of income, trade liberalization appears to be statistically positively significant at the 5-percent level of significance, increasing income inequality by $0.08 \%$. Results are according to expectation and satisfactory. Due to liberalization, the proportion of labor in production has declined while capital has increased. Thus their returns have also changed with distribution of income getting concentrated more in favor of capital owners. PGDP appears to

\footnotetext{
${ }^{5}$ AR (2) was used, as AR (1) could not solve the problem of auto-correlation.
} 
significantly reduce inequality of income distribution in the country. Specifically expressed, a 1 percent increase in PGDP has been found to be associated with 0.8 percent decline in income inequality. However, inflation, as expected, has influenced distribution of income very adversely. Unlike PGDP, which has decreased income inequality, inflation has increased inequality in Pakistan during the study period. The effect of inflation on income distribution observed in this analysis is in agreement with what is shown by Fischer (1993). ${ }^{6}$

The effect of trade liberalization on PGDP, as reflected in the third regression equation is interesting. Increase in liberalization has tended to decrease PGDP. This is in conflict with prior expectations. It may be due to the introduction of certain policies concerning investment and import substitution, which could not lead to higher economic growth and increased level of PGDP on liberalization of trade. Another possible reason could be the increasing use of such technologies which encourage capital intensive rather than labor-intensive methods of production. Since a large proportion of the national labor force is semi-skilled or unskilled, its productivity under the use of high tech capital method of production did not increase significantly. As to the effect of employment on PGDP, it has affected PGDP positively. Specifically, a one-percent increase in employment has been found to be associated with a 1.6 percent increase in PGDP. Similarly, the type of government also appears to be affecting PGDP highly positively.

The case of the effect of trade liberalization on employment has been found to be different from that on other development indicators. Employment has been affected significantly and positively by trade liberalization due principally to increases in imports and availability, and generation of resources, which led to increased production and employment level in the country. Increases in exports stimulates demand not only for imported inputs but also for labor, leading ultimately to an increase in the employment level in the economy. PGDP has also affected employment significantly positively. Specifically, a 1 percent increase in PGDP has been found to increase employment by 0.9 percent.

\section{Conclusion and Policy Implication}

While trade liberalization is regarded as encouraging development by affecting development indicators in a desirable manner, it has not influenced the chosen indicators of poverty, income distribution, PGDP and employment in Pakistan as expected during the period of study. It

${ }^{6}$ c.f., Kemal et. al. (2002). 
affected employment positively but PGDP negatively in the country. Increased imports, availability of cheap raw material and machinery under conditions of unrestricted trade on the one hand enhances production, while exports of manufactured goods on the other hand, led to the creation of additional employment opportunities in the country due mainly to increase in demand for domestic goods. The reason behind trade liberalization affecting PGDP adversely may be that although imported products are expected to be cheaper than local products, it has not been the case for Pakistan. Imported products served as one of the factors which increased the prices of local goods with adverse effects on their demand and production and thereby on PGDP.

As far as poverty and Gini coefficients are concerned, trade liberalization has contributed to the accentuation of income inequality in the country, although it left poverty unchanged. This may be attributed to the poor performance of mediating factors in Pakistan. It may thus be argued that trade liberalization has not affected development favorably in Pakistan. It may not be the fault of just liberalization policies themselves but also of the mediating factors of our economy.

The study has the following policy implications.

- Since Pakistan is a labor abundant country, it should give priority to the production and export of labor-intensive products, such as textiles.

- For poverty alleviation the productivity-oriented approaches, with the potential to increase the income of the poor by increasing their productivity, should be encouraged.

- Political stability which is one of the most effective factors of development, should be promoted in the country. Improved political stability has favorable implications. In the last fifty years Pakistan has faced several changes in government and consequently changes in economic policies. To improve economic performance, the country should improve political stability.

- Pakistan should improve the performance of its mediating factors for trade liberalization to be effective in promoting growth and development. 


\section{Appendix}

Table A-1: Estimates of Simultaneous Equation Model (Import Duties as Trade liberalization index)

\begin{tabular}{|c|c|c|c|c|}
\hline Variables & $\begin{array}{l}\text { Eq. } 1 \\
\text { (L P) }\end{array}$ & $\begin{array}{c}\text { Eq. } 2 \\
\text { (LG) }\end{array}$ & $\begin{array}{c}\text { Eq. } 3 \\
\text { (LPGDP) }\end{array}$ & $\begin{array}{c}\text { Eq.4 } \\
\text { (LEMP) }\end{array}$ \\
\hline $\mathrm{C}$ & $\begin{array}{r}0.5617 \\
(0.861)\end{array}$ & $\begin{array}{l}0.666^{* * *} \\
(2.22)\end{array}$ & $\begin{array}{c}0.43^{*} \\
(4.04)\end{array}$ & $\begin{array}{l}-0.382^{*} \\
(-6.07)\end{array}$ \\
\hline LGINI & $\begin{array}{c}1.6118 \\
(1.398)\end{array}$ & - & - & - \\
\hline LPGDP & $\begin{array}{l}-3.25^{* * *} \\
(-1.628)\end{array}$ & $\begin{array}{l}-0.835^{*} \\
(-3.918)\end{array}$ & - & $\begin{array}{r}.863^{*} \\
(13.75)\end{array}$ \\
\hline LEMP & $\begin{array}{l}-5.76^{* *} \\
(-2.132)\end{array}$ & - & $\begin{array}{c}1.055^{*} \\
(5.185)\end{array}$ & - \\
\hline LCPI & - & $\begin{array}{l}0.258^{*} \\
(4.09)\end{array}$ & - & - \\
\hline LHK & - & - & $\begin{array}{l}-0.003 \\
(-0.03)\end{array}$ & - \\
\hline LINV & - & - & - & - \\
\hline TG & - & - & $\begin{array}{c}0.045^{*} \\
(2.97)\end{array}$ & $\begin{array}{l}-0.055^{*} \\
(-3.49)\end{array}$ \\
\hline LW & - & - & - & $\begin{array}{c}0.088 \\
(1.439)\end{array}$ \\
\hline TL & $\begin{array}{l}-0.334^{* *} \\
(-2.24)\end{array}$ & $\begin{array}{l}-0.036 \\
(-0.79)\end{array}$ & $\begin{array}{l}0.106^{* *} \\
(2.11)\end{array}$ & $\begin{array}{l}-0.171^{*} \\
(-2.69)\end{array}$ \\
\hline $\mathrm{R}^{-2}$ & 0.66 & 0.61 & 0.97 & 0.97 \\
\hline D.W & 1.44 & 1.36 & 1.07 & 1.29 \\
\hline $\operatorname{AR}(2)$ & $\begin{array}{c}-0.025 \\
(-0.132)\end{array}$ & $\begin{array}{c}0.378 \\
(2.89)\end{array}$ & $\begin{array}{c}0.286 \\
(1.42)\end{array}$ & $\begin{array}{c}0.133 \\
(0.67)\end{array}$ \\
\hline
\end{tabular}

Note: 1) t-values are in parentheses.

2) $* * *$ and $* * *$ indicate significance at $1 \%, 5 \%$ and $10 \%$ level of significance, respectively. 


\section{References}

Abbas, Q., 2001, "Endogenous Growth and Human Capital: A Comparative study of Pakistan and Sri Lanka”, Pakistan Development Review, 40:4, 987-1007.

Behrman, J. and Srinivasan T.N., 1995, "HandBook of Development Economics”; Elsevier Science: The Netherlands.

Chenery, H. and Srinivasan T.N., 1989, "HandBook of Development Economics"; Elsevier Science: The Netherlands.

Edwards, S., 1993, "Openness, Trade Liberalisation, and Growth in Developing Countries”, Journal of Economic Literature, 31:3. 1358-1393

Mahbub ul Haq Human Development Centre, 2003, "Human Development in South Asia 2003”, Oxford University Press, Islamabad.

Govt. of Pakistan, 2003, Economic Survey, (Various Issues) FBS, Islamabad.

Govt. of Pakistan, 2003, Trade policies (Various Issues), Ministry of Commerce, Islamabad.

Greenway, D., M., Wyn. and Wright, P., 2002, "Trade Liberalisation and Economic Growth in Developing Countries”, Journal of Development Economics, 67:1. 229-244.

Hunt, D., 1989, "Economic Theories of Development: An analysis of competing paradigm", Harvester Wheatsheaf: USA.

Irwin, A. Douglas and Tervio, M., 2002, "Does trade raise income? Evidence from the twentieth century", Journal of Development Economics, 58:1.118 .

Kema1, A.R., Din, Musleh-ud., and Qadir, U., 2002, "Global research Project: Pakistan Country Report on Sources of Economic Growth”, Pakistan Institute of Development Economics: Islamabad.

Mohsin, M. H., Kemal, A. M., and Qadir, U., 2001, "Impact of Trade Reforms on Poverty”, Pakistan Institute of Development Economics, Sixteenth Annual General Meeting: Islamabad.

Waczairg, R., 1998, "Measuring the dynamic gains from trade”, World Bank Policy Research Working Papers 2001. 
Yang, Y. and Haung Y., 1997, "Impact of Trade Liberalisation on Income Distribution in China”. Economic Division Working Papers No. 1. 